\title{
Correction to: PIM1 mediates epithelial- mesenchymal transition by targeting Smads and c-Myc in the nucleus and potentiates clear-cell renal-cell carcinoma oncogenesis
}

Bin Zhao, Lei Liu, Jun Mao, Zhiwei Zhang, Qifei Wang and Quanlin Li

Correction to: Cell Death and Disease

https://doi.org/10.1038/s41419-018-0348-9

published online 22 February 2018

The original version of this article unfortunately contained a mistake in Fig. 6D. The correct figure can be found below. The authors apologize for the mistake. The original article has been corrected.

Published online: 04 March 2021

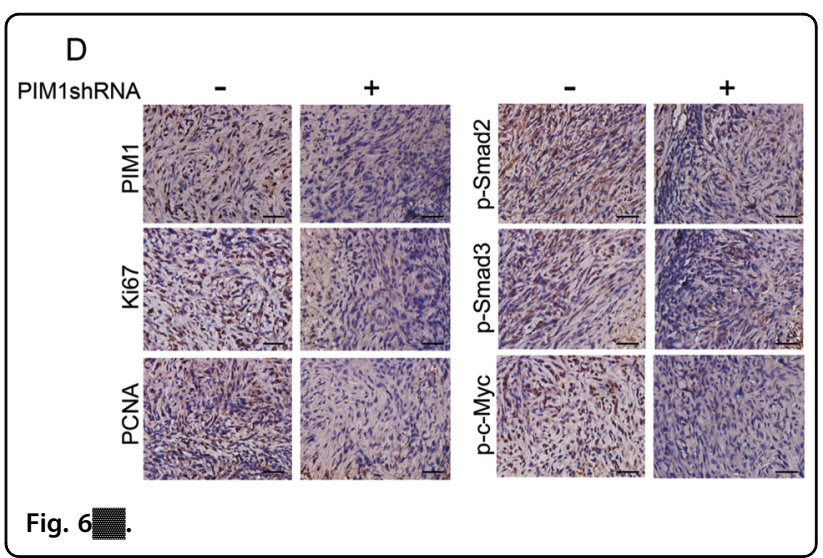

(c) (i) Open Access This article is licensed under a Creative Commons Attribution 4.0 International License, which permits use, sharing, adaptation, distribution and reproduction in any medium or format, as long as you give appropriate credit to the original author(s) and the source, provide a link to the Creative Commons license, and indicate if changes were made. The images or other third party material in this article are included in the article's Creative Commons license, unless indicated otherwise in a credit line to the material. If material is not included in the article's Creative Commons license and your intended use is not permitted by statutory regulation or exceeds the permitted use, you will need to obtain permission directly from the copyright holder. To view a copy of this license, visit http://creativecommons.org/licenses/by/4.0/. 